\title{
Transhumant agro-pastoralism in Bhutan: Exploring contemporary practices and socio-cultural traditions
}

\author{
Kuenga Namgay ${ }^{1 *}$, Joanne Millar ${ }^{1}$, Rosemary Black ${ }^{1}$ and Tashi Samdup ${ }^{2}$
}

\author{
* Correspondence: \\ kuenga007@gmail.com \\ ${ }^{1}$ School of Environmental Sciences, \\ Charles Sturt University, Albury, New \\ South Wales 2640, Australia
}

Full list of author information is available at the end of the article

\begin{abstract}
This paper presents research findings on the contemporary practices and socio-cultural traditions of transhumant agro-pastoralism (TAP) in Bhutan. Despite the widespread practice of TAP in Bhutan, there has been limited research on the nature of the practice and associated socio-cultural traditions. Qualitative research methods were used to interview 24 migrating households and nine relevant agency staff in 2010. A structured survey of 75 TAP households gathered background quantitative data.

Migration takes place in April/May and September/October, and may take four days to over a month. The main reasons for migration include (1) avoiding production reduction and mortality of animals from cold, (2) shortage of forage, (3) off-farm income opportunities, (4) avoiding parasite infestation in the south and (5) vacating grazing areas for yaks in winter. Additionally, the study revealed that there are several other factors and indicators that herders consider in planning their seasonal transhumant movement.

We conclude that TAP is an important part of the living cultural heritage in Bhutan. TAP herders have not only adapted their livelihoods to ecological niches at different altitudinal levels but also used resources sustainably while synchronizing their sociocultural activities with seasonality of the transhumant practice. However, the system is under increasing pressure. Today, TAP communities are faced with family labour shortages due to the increasing participation of children and adults in education and alternative livelihood options. They also face policy and climate change issues making their TAP practice more difficult. Strategies are needed that will allow herders to make informed choices about their futures.
\end{abstract}

Keywords: Adaptation, Bhutan, Livelihood, Livestock, Pastoralism, Rangeland, Migration, Transhumance

\section{Background}

Transhumant agro-pastoralism is the seasonal migration of livestock and humans from one agro-ecological zone to the other and back, from an established permanent home base with some cropping (Evans 1940; Rota and Sperandini 2009; Waters-Bayer and Bayer 1992). Mobility is key to transhumant pastoral systems, enabling herders to move their livestock at different points in time, exploring ecological niches provided by microclimates at different agro-ecological zones, efficiently utilizing available resources, averting risks and producing food from land with no opportunity costs. It is 
one of the main strategies used by pastoralists to access natural resources such as pasture and water (Dyson-Hudson and Dyson-Hudson 1980; Fernandez-Gimenez and Le Febre 2006; Niamir-Fuller 2005).

Transhumant mobility and increases in herd size during favourable seasons for pastoralists are also a necessary action to offset the potential high losses resulting from extremely unpredictable climates (Behnke 1983; Ellis and Swift 1988; Sandford 1983; Scoones 1994). Transhumant movements may cover ten to hundreds of kilometres, allowing livestock to cope with the seasonality of forage availability and enabling conversion of low-value ephemeral forage to high-value livestock and its products (Boone et al. 2008). Mobility, however, is not an easy task. It involves resources, mainly family labour, and requires investment in making, building and maintaining social capital necessary to access vital resources. Mobility also puts the pastoralist in the face of disasters and subject to changing social and political conditions (Boone et al. 2008).

An estimated population of around 10 million livestock-dependent people are known to inhabit the Himalayan mountain grazing lands, including Bhutan (McVeigh 2004; Miller 1995). Various forms of pastoralism, including transhumant agro-pastoralism, have allowed Himalayan herders to transform these extensive but physically marginal rangelands into economically productive areas (Miller 1995; Mishra et al. 2010; Ura 2002).

The Himalayan pastoral system resembles that of Central Asia (Kerven et al. 2011; Misra 2009) wherein their uniqueness that distinguishes them from African pastoralism is that for Himalayan pastoralism, altitude and temperature, as opposed to the availability of water, separates pastoral grazing lands from cropping land (Miehe et al. 2009; Miller 1995). Pastoralism and transhumance in this region occurs in areas that are remote and forested and in open highlands where cropping is not always successful owing to cold temperatures and short growing seasons.

Transhumant mobility is crucial for Himalayan pastoralists to be able to tap the resources at the right time in a heterogeneous environment (Miller 1995). Mobility also takes advantage of diversification options that increase the pastoralists' incomes, such as marketing their products or utilising their physical capital endowment such as working as porters in the case of the Tamang people in Nepal (McVeigh 2004).

This paper presents the findings of a study exploring the contemporary practices of transhumant agro-pastoralism (TAP) in Bhutan. Despite the widespread practice of TAP in Bhutan, there has been limited research on the nature of the practice and socio-cultural traditions associated with the TAP system.

\section{Study area}

The Kingdom of Bhutan is a landlocked country located in the eastern Himalayas, which shares borders with India to the east, west and south and the Tibet Autonomous Region of China to the north. The country is mostly mountainous with a land area of about 38,000 sq $\mathrm{km}$ and an estimated population of 730,000 (NSB 2007). Forest covers more than $70 \%$ of the land area with nearly 7\% remaining under year-round snow and glaciers (NSB 2011).

Bhutan is largely an agrarian country with $69 \%$ of the population living in rural areas and engaged in agriculture (NSB 2008; PPD 2008). Livestock forms an integral part of the agricultural system, contributing not only to the human diet but also to soil fertility and draught power. About $90 \%$ of the rural Bhutanese population keep some form of livestock (RGoB 2009). 
Livestock contributes 7\% to the national GDP, and it has been estimated that about $22 \%$ of rural household income is produced from the rearing of livestock (MoA 2009). Cattle constitute the main species of livestock kept in four systems that can be broadly categorised as (1) alpine transhumant yak pastoral system, (2) cattle-based TAP, (3) cattle-based local transhumance in a mixed system and (4) cattle in a sedentary mixed farming system found in most villages as well as in peri-urban areas. The cattle-based local transhumance system involves keeping and moving cattle between pastures around villages. The herd is brought home to the cropping fields after crop harvest so as to fertilize the fields.

The cattle-based TAP system, on the other hand, moves seasonally, often crossing different districts' administrative boundaries. These herders keep large herds of Bos indicus type of cattle, locally known as Thrabam ${ }^{\mathrm{a}}$, Nublang or Siri, and Mithun ${ }^{\mathrm{b}}$ (Bos frontalis) crossbreds (Mithun X Thrabam), with a few horses and sometimes pigs, goats, sheep and dogs. Thrabam and Mithun crossbreds, the majority of which are reared through the TAP system, accounted for $82 \%$ of the bovine population in 2008 (MoA 2009). European breeds are not commonly found in such herds, owing to the extensive nature of the pastoral system where animals are let loose in the forests to graze with little supplementary feed except for occasional salt supplements. Pastoral cattle have evolved with the environment and have adapted their physiological and behavioural patterns to the transhumant practices.

The study was conducted in six different TAP villages, four in the west and two in the central-east region of Bhutan (Figure 1). These villages were selected because the majority of people in these villages practice TAP and are heavily dependent on their transhumant cattle system.

The six villages studied were Papali, Bempu, Tshebji and Damchena in the west and Urchi and Doshi in central-east Bhutan. The study sites ranged in altitude from 2,812

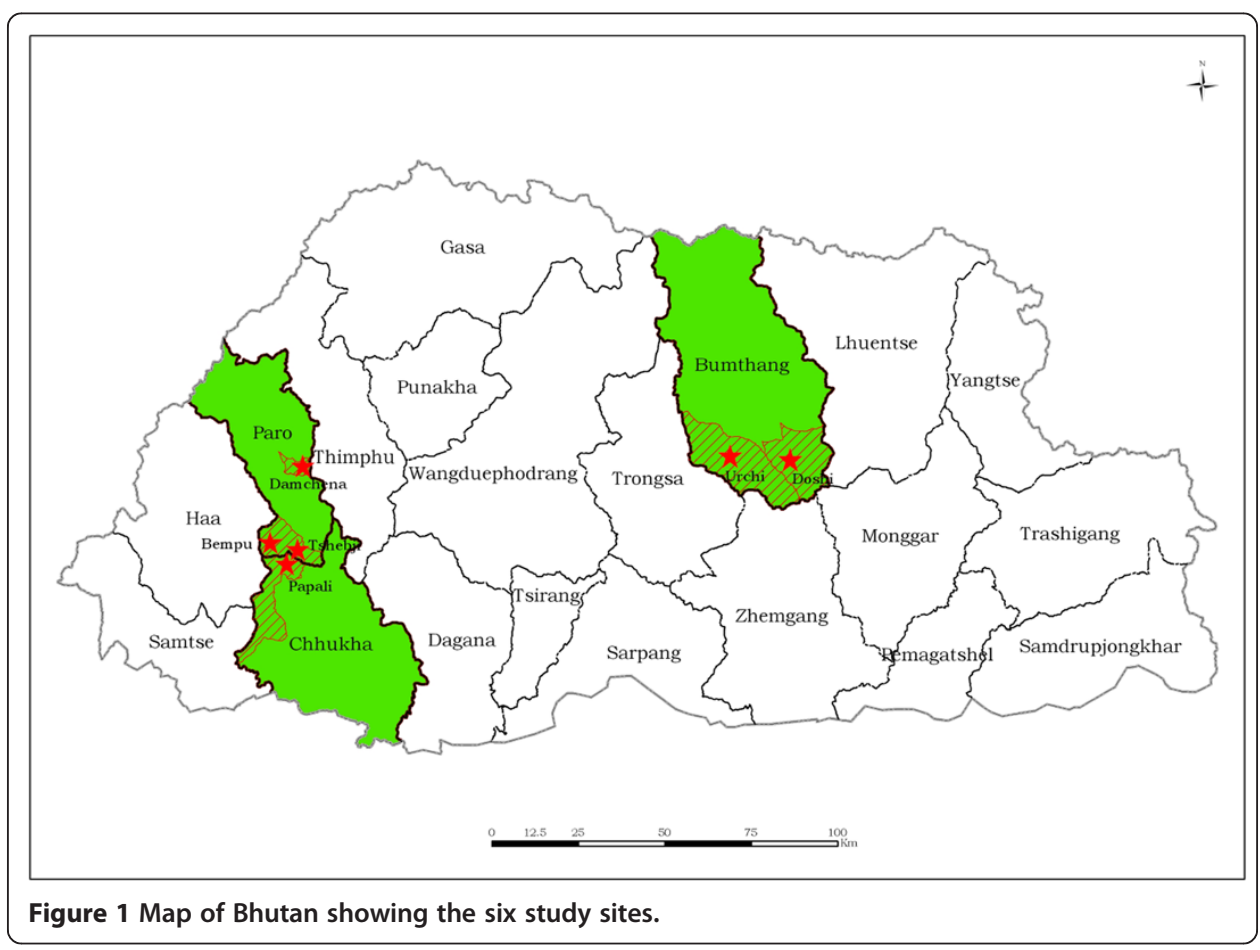


to $3,227 \mathrm{~m}$ above sea level. However, their winter grazing areas are located at much lower altitudes in sub-tropical forests.

\section{Methods}

Qualitative research methods were used to interview 24 migrating households from the six villages and nine agency staff (six government and three non-government) across the study sites over a three-month period in 2010. A semi-structured household survey gathered background quantitative data of 75 migrating households. The nine government and non-government agency informants were chosen based on their knowledge of livestock development in Bhutan, experience and knowledge in forestry policies and rules, and direct or indirect involvement with livestock development policies.

Purposive and snow-ball sampling of participants was used to identify those with prior experience of the cattle-based TAP system so as to understand the contemporary practices (Noy 2008). Snow-ball sampling - one of the most commonly used sampling techniques in inter-disciplinary qualitative social science research - is a repetitive process whereby one key informant refers the researcher to the other, and so on. Its evolving snow-ball effect builds up the bulk of relevant informants whose life experience and knowledge are the key focus of the researcher (Noy 2008). All in-depth interviews with TAP key informants and household surveys were conducted face-to-face in the native language - Dzongkha. In-depth interviews with open-ended questions formed the core tool for this research in exploring herders' experiences and in eliciting issues (Tong et al. 2007). Household surveys took place with the family, the husbands and the wives answering most of the questions, sometimes supplemented by their adult children.

\section{Data analysis}

The audio recordings of the interviews conducted in the local language were translated and transcribed into Word documents in English. Interviews with the agency experts were carried out in English which enabled direct transcription. Listening to audio records allowed the researcher to become familiar with the data and achieve a certain level of analysis during the transcription process. Household survey data were analysed for descriptive statistics using only MS Excel 2010. Survey questions were in English, while in the field the questions were translated and asked in Dzongkha. However, because the answers were directly translated and written down in English during the survey, the data were directly transferrable onto MS Excel tables for analysis. The results obtained were incorporated with qualitative data to support the arguments arising from qualitative data and used to describe the demographic and socio-economic background of the study areas.

The in-depth interview analysis followed open, axial and selective coding in line with the process for grounded theory generation (Creswell 1998; Westbrook 1994). Once all the in-depth interview transcripts were uploaded into the computer, inductive analysis was performed allowing for patterns, themes and categories to emerge out of the data (Patton 1990). For every research question, cross-interview analysis was performed, pulling together answers from different key informants for the same question (Patton 1990) to draw broader patterns with categories and sub-categories under each theme. Each transcript was skimmed through for each question, and all answers to each question from different informants were pulled and grouped together. Broad themes, categories and patterns 
Table 1 Comparative cattle herd size between western and central-east regions $(n=75)$

\begin{tabular}{lcccccc}
\hline Region & \multicolumn{3}{c}{ Western region } & \multicolumn{2}{c}{ Central-east region } \\
\hline Villages & Tshebji & Papali & Damchena & Bempu & Urchi & Doshi \\
Total & 339 & 260 & 302 & 458 & 1621 & 413 \\
Average per household & 30.8 & 28.9 & 50.33 & 45.8 & 64.84 & 29.5 \\
\hline
\end{tabular}

arising from the transcripts were then grouped and written up accordingly, using relevant quotations to show or allow data to tell the story (Patton 1990).

All the key informants and household survey respondents were coded, and their names were not used in quotations to protect their identity (Dunn 2005). These understandings generated from the interviews were supported by notes and memos taken from casual conversations in the field, joining the herders in their camps, visiting their pastures and whilst transporting their products to market.

\section{Results}

The average household size was 8.3 persons per household with a total of 621 people across the six villages. More than half the population (65\%) were within the age bracket of active labour force (15 to 60 years). Around $20 \%$ were 14 years and below, and the other $15 \%$ were 61 years and over. In total, there were 3,393 head of cattle comprising all prevalent cattle breeds with an overall average of 45 head per household. The average cattle numbers per household ranged between 29 and 65 between villages, regardless of region (Table 1).

As indicated below (Table 2), there were, however, large inter-household differences in the number of livestock species in all the villages across the two regions, with none owning sheep.

The average cropping land ownership was 2.55 ha per household but with huge inter-community differences. The average landholding of western Bhutan TAP was 1.54 ha per household, while those of the central-east sites were about double the size at 3.52 ha per household.

\section{The contemporary nature of transhumant agro-pastoralism in Bhutan}

In this section, the contemporary nature of TAP is discussed, followed by socio-cultural traditions associated with the TAP system.

The following sections start with reasons necessitating transhumant movement. The section begins with the economic reasons, but more importantly we discuss the bio-physical factors that necessitate TAP herders to engage in seasonal inter-Dzongkhag ${ }^{\mathrm{c}}$

Table 2 Household holdings of different livestock species $(n=75)$

\begin{tabular}{|c|c|c|c|c|c|c|}
\hline & Cattle & Horses & Mules & Donkeys & Pigs & Poultry \\
\hline Mean & 45.24 & 4.25 & 2.41 & 0.12 & 0.24 & 2.83 \\
\hline Standard deviation & 26.75 & 3.54 & 3.81 & 0.33 & 0.61 & 3.12 \\
\hline Range & 123 & 20 & 15 & 1 & 3 & 13 \\
\hline Minimum & 4 & 0 & 0 & 0 & 0 & 0 \\
\hline Maximum & 127 & 20 & 15 & 1 & 3 & 13 \\
\hline Sum & 3,393 & 319 & 181 & 9 & 18 & 212 \\
\hline
\end{tabular}


(i.e. between administrative districts) transhumant movement with their animals. This is followed by a brief discussion on breeds of animals, migration routes, the timing of migration, indicators and factors that herders consider while planning the journey, nature of grazing rights types, impact of TAP on children's education and gender roles in TAP practice.

\section{Why transhumance is necessary}

The study findings revealed that there were five main reasons why transhumance occurs. These are summarised in Table 3. However, owing to their inter-connectedness, these reasons are discussed in tandem rather than independently. The main factors necessitating south-bound migration were very low temperatures and the lack of grazing land and shortage of feed for animals in temperate villages in winter, which results in high mortality of animals. Herders explained how, in winter, the pastoralists' villages become extremely cold with snow and frost, evening temperatures often dropping to sub-zero. Everything around the village locations dries up, leaving no forage for their animals to graze. The herders reported that the frigid temperatures not only diminish milk production but also result in high mortality of animals.

They also indicated that their animals are a local breed that are used to the transhumance system and would die of cold and feed shortage if not moved to the south in winter.

One elderly herder emphasized the need to migrate as there was nothing in the village locations in winter for animals to feed on:

"... how can we survive here? So many animals, there is nothing to feed them in winter. Cattle are already running away." (Herder_8)

Herders also explained that shortage of land was not only in terms of private land to accommodate and feed the animals in winter but also because their summer pastures were being occupied by Bjobs ${ }^{\mathrm{d}}$ (alpine yak herders) in winter, necessitating cattle to be moved further south. Summer pastures for cattle become winter pastures for the yaks.

A male herder in his forties from Damchena said:

“... in winter these Tsamdros ${ }^{\mathrm{e}}$ here belong to Bjobs rearing yaks. Those Bjobs from Bjeyla, although they belong to Thimphu Dzongkhag and Lingzhi Geog ${ }^{\mathrm{f}}$... in winter they say it belongs to them ... although the Tsamdro is in Paro. Our rights to these Tsamdros are restricted only to summer, in winter it belongs to Bjobs ... that [non-migration] will lead to death of all our cattle." (Herder_36)

Table 3 Frequency $(F)$ of factors necessitating transhumance mentioned by the herders

\begin{tabular}{lcc}
\hline Factors necessitating transhumance & $\boldsymbol{F}(\boldsymbol{n}=\mathbf{2 4})$ & Percentage \\
\hline 1. To avoid the harsh winter cold and mortality of animals owing to high altitude & 15 & 62.50 \\
2. No space (enough land) and shortage of feed at temperate village in winter & 14 & 58.33 \\
3. To engage in the off-farm activities (transportation, petty contract and packaging) & 6 & 25.00 \\
$\begin{array}{l}\text { 4. To be able to take care of their animals, avoid animal parasites in the south, be able } \\
\text { to grow crops in the village and supply draught power and manure for the crops }\end{array}$ & 5 \\
$\begin{array}{l}\text { 5. Because the summer Tsamdro in winter will be grazed by Bjops } \\
\text { 20.83 }\end{array}$ & 46.67 \\
\hline
\end{tabular}


TAP herders also mentioned not having enough private land to grow pasture and crops and to graze their cattle as another reason for transhumance. Owing to the small landholdings, herders considered livestock of primary importance compared to crop production. Herders informed us that because of inadequate landholding and the remote location of their villages - situated between the mountains at higher altitude they are not self-sufficient in food without practicing transhumance with their cattle and exploring other opportunities. The only annual crops suitable at that altitude are wheat, barley and buckwheat, which have low yields owing to these limitations.

An elderly herder in Doshi said:

"... livestock is a must for us. Butter and cheese are our main livelihood support products. There is potato but it is unpredictable, when the price is good it is better but when the price is down it cannot even pay its transportation charge ... In Doshi even these crops do not grow properly. So, livestock is the only reliable source for us. Our parents have done that and we also need it." (Herder_6) (Figure 2)

Another Doshi herder gave similar reasons and indicated livestock products as being more reliable than crops. The household survey revealed that about half of the herders interviewed believed they have enough land to theoretically meet their household food needs. However, only $40 \%$ of the respondents reported being able to produce enough food from their land. Reasons cited were the inability to cultivate all the land they owned, land fragmentation, land located far away from house, wild animal depredation and dependence on traditional farm equipment.

These marginal landholdings and fragmentation were further exacerbated when the government allotted part of their Tsamdro customary landholdings (discussed in the 'Types of grazing rights to pasture resources' section) to new immigrant settlers in the south in the 1970s. The herders indicated that in the past some of them initially leased part of their Tsamdros to early Lhotshampa (term used in Bhutan to refer to southern Bhutanese of Nepalese ethnicity) settlers. Herders said that as new settlers started settling in the south they cultivated part of herders' Tsamdro land and paid annual rents in kind. This became one of the incentives for the herders to migrate seasonally. However, this

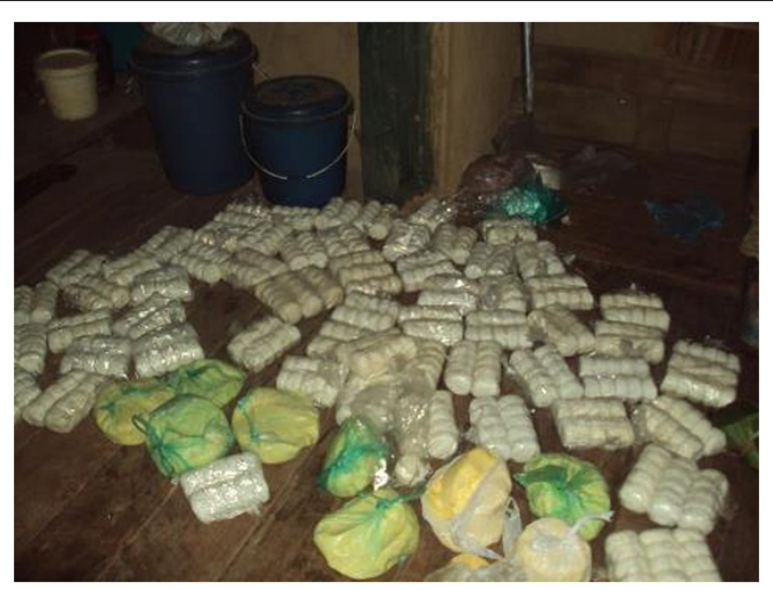

Figure $\mathbf{2}$ Locally produced butter and cheese ready for market. 
practice of renting part of Tsamdro was said to have ended after the government allotted land to the settlers in their own name. This reduction in Tsamdro grazing areas led herders to look for additional income-generating activities to supplement their income and food produced from their cattle and smaller landholdings.

About $90 \%$ of the herders indicated that they are engaged in seasonal work such as transporting oranges in winter, carrying tourist equipment and construction materials, making cane products, working as casual labour at construction sites and other cottage industries such as yathra (woollen cloth material) weaving. Orange harvest and export starts late November and lasts till early February. This season in the south coincides well with the time when TAP herders are in their winter camps. For a long time, TAP families have been involved in a range of activities in the process of exporting these oranges mainly to Bangladesh. TAP families either do petty contracts like middlemen in handling the fruits or transporting them from remote orchards to the road head, or women and girls engage in packing the fruits in the boxes. These activities form one of the main cash income opportunities for TAP families in winter for those that migrate far down enough to reach orange-growing areas. Those that do not go that far engage in making baskets and other cane products, mainly for their domestic consumption. However, irrespective of the amount of income they earned seasonally or crops harvested from their fields, nearly $90 \%$ of herders rated cattle as important to highly important for their household's livelihood.

The following section shows that transhumance is necessary not only because of economic reasons but additionally because the cattle breeds raised by the TAP herders are adapted to such system.

\section{Cattle breeds kept by the TAPs: Jatshams and Thrabams preferred over exotic breeds}

The interviews revealed that the traditional cattle breeds which are well adapted to the transhumance system are predominantly Thrabams and Jatsha-Jatshams ${ }^{\mathrm{g}}$ crossbreds. Thrabams are an indigenous breed of cattle of Bos indicus type also referred as Siri or Nublang. The Mithun (B. frontalis) originates from Arunachal Pradesh State in India. Herders indicated that they crossbreed Mithun with Thrabams to produce Jatsha-Jatshams crossbreds, for higher milk production, high butter fat content, the superior strength of these animals which are well suited for ploughing and pack animal purposes, and the ability to walk long distances, negotiate steep and narrow landscape and graze in the forest ${ }^{\mathrm{h}}$ (Figures 3, 4 and 5).

Indicating clear preference of Thrabams and Jatsham crossbreds for their favourable quality of being raised in the transhumance system, a herder in Bumthang, when asked about his herd composition, said:

“... I have 30-40 heads - Jatshams and Thrabams. I don't have exotic breeds like Jersey ... there is shortage of fodder in winter, so definitely animals will die."

(Herder_4)

Herders also reported the existence of Yangkums (Jatshams backcrossed to Nublang bull) within Thrabam and Jatsham herds. This trend is not preferred and suggests an outcome of labour shortage, such that selective breeding practices are constrained. One elderly male herder from Doshi mentioned maintaining pure Jatsham herds in the past. He took 


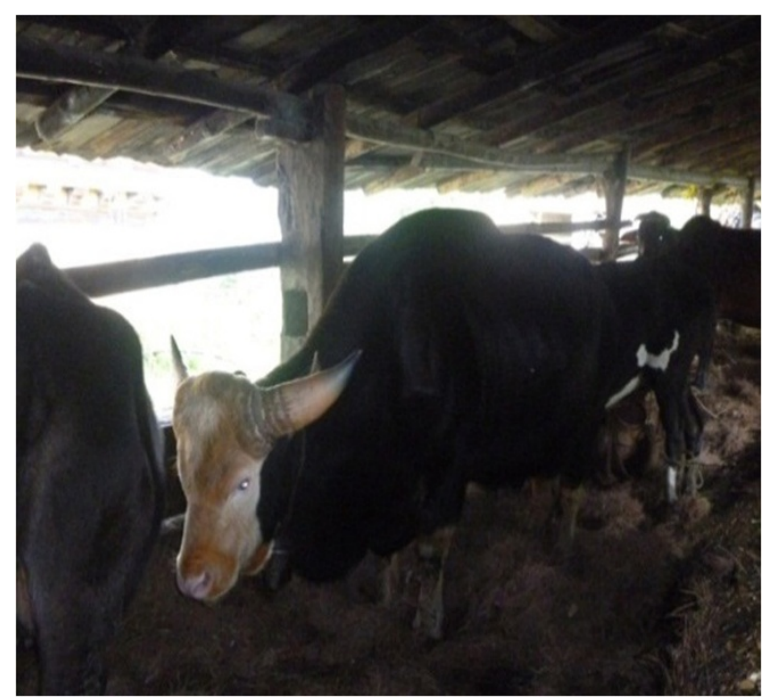

Figure 3 Pure Mithun bull.

Yangkums to other Dzongkhags like Wangdiphodrang, sold them, bought and brought back pure Jatshams and maintained a pure Jatsham herd. Now, he said that due to labour shortages he could not go and sell his Yangkums nor purchase Jatshams:

"I used to take Yangkums and sell them and buy Jatshams in return to maintain pure Jatsham herd for higher productivity. But I cannot do it now so the herd comprises mixed breeds and productivity has declined." (Herder_6)

The TAP herds today continue to be dominated by Thrabams and Jatshams. While some report improvements in their herd by replacing largely Thrabam herds by Jatshams, others lament the deteriorating herd quality due to Thrabams, from once having pure Jatsham herds. The ability to convert the herd into more Jatshams is considered as progress in the herders' world view.

The interviews with herders revealed that they are not confident enough to shift to exotic breeds of cattle because of the high cost involved, the perceived fragile health

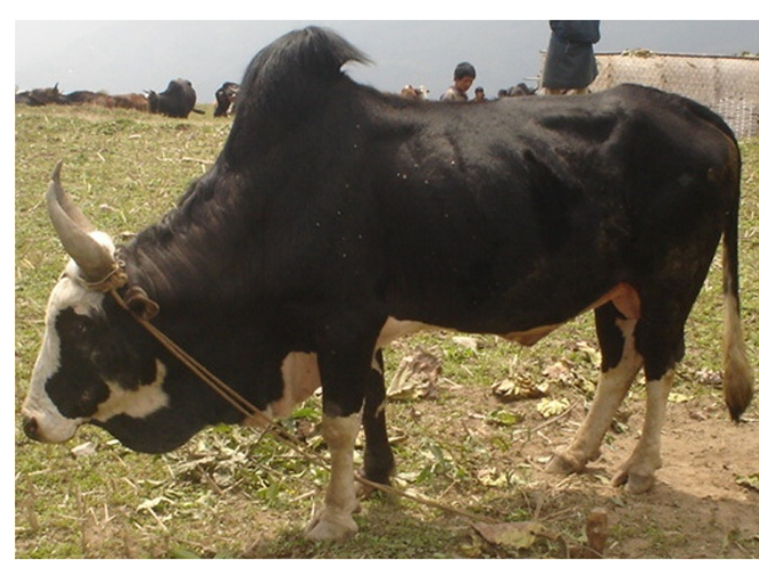

Figure 4 Thalang/Siri/Nublang bull (indigenous). 


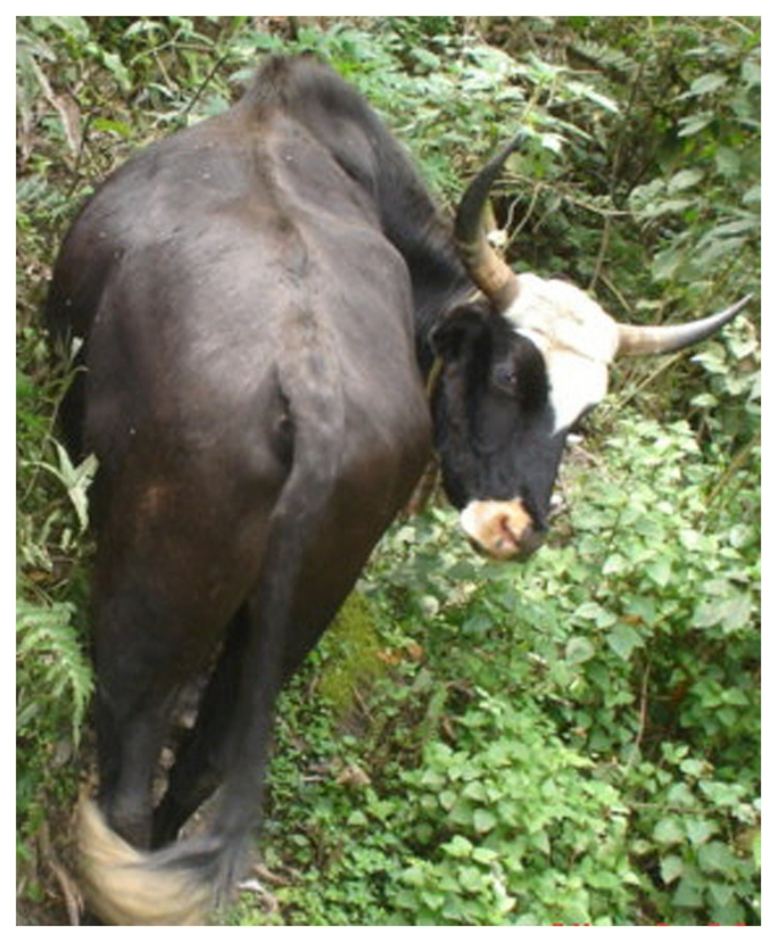

Figure 5 Jatsha oxen.

and high level of management required for the exotic European breeds. Even today, most herders reported having only a few or no exotic breeds of cattle, particularly Jersey and Brown Swiss, which continue to be promoted by the Bhutanese government for crossbreeding with the local Thrabams.

A female herder in Tshebji said, “... for poor farmers like us, we cannot afford to buy exotic crossbreds, besides sometimes these animals die suddenly and cause huge loss." (Herder_32)

Many young herders appeared sceptical about ceasing transhumance based on indigenous cattle and instead sedentarizing their farm by adopting exotic cattle breeds. A young herder from Bempu said:

"I feel we would be doing it the same way as our parents did. Exotic breeds like Jerseys are difficult to manage and very fragile and die very easily. Our Jatsham breeds are very thrifty, easy to rear and live a long life." (Herder_18)

The same perception was found in Urchi. Herders in general believed that the majority of them are not ready to provide the level of management these exotic dairy cattle crossbreds need. Clearly, the herders' preference is for Jatsham and Thrabam breeds for reasons of superior survival and the thrifty characteristic of local breeds over exotic dairy cattle. The higher butter fat content and possibility of keeping a higher number of cows in milk with migrating local breeds also raise the prospect of better income.

The migration routes and length of migration

The herders and government agency informants reported the existence of established migration routes that the herders follow regularly, including camp sites they use 
during migration and final camps where they erect semi-permanent sheds in winter (Figures 6 and 7). The interviewees also indicated that the transhumance journey in a single direction could be between four to five days and over a month long. The shortest migration route was reportedly the Jabana (Tshebji and neighbouring areas)-Dungna route which could be reached in four to five days (Figures 6, 8 and 9).

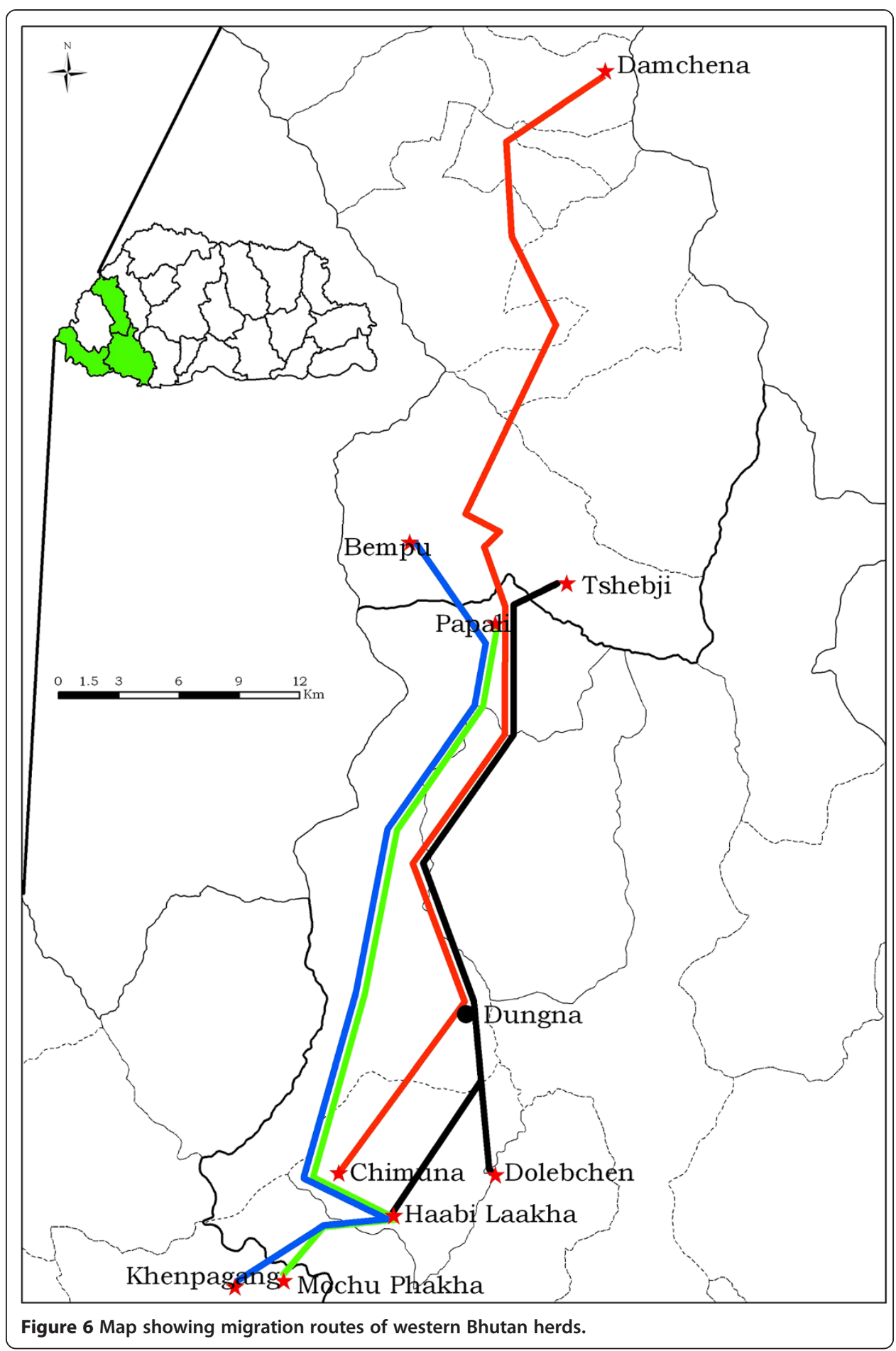




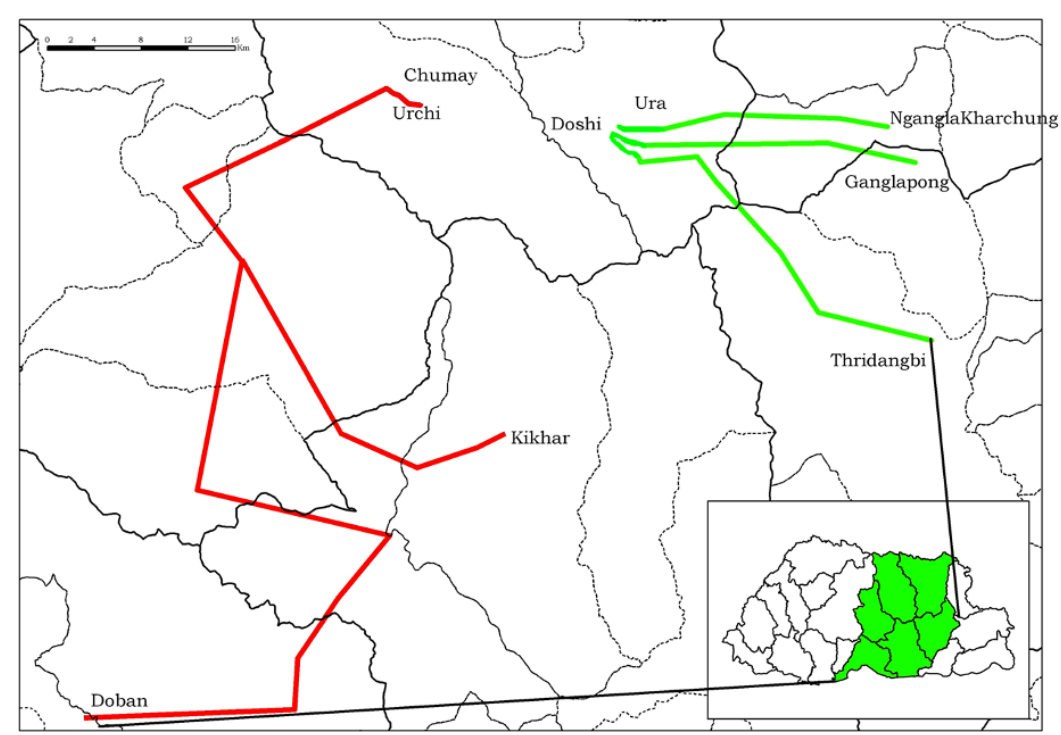

Figure 7 Map showing migration routes of central-east Bhutan herds.

The longest route (Figure 7), as reported by a female herder in Urchi, is the Urchi (Bumthang)-Doban (Sarpang) route that takes over a month to reach the final destination in one direction.

The herders said that the routes they follow were those used by their parents and are so established that even their animals know these places very well. A female herder in Tshebji said:

"It has been designed that way for a long time. The animals know already where to halt. If we have halted at certain places last year, this year when the herd moves the animals will stop as soon as they have reached those camp sites."

(Herder_32)

However, on a daily basis the herds usually move shorter distances and also halt several days along the way for various reasons. Some halts are the result of the herders'

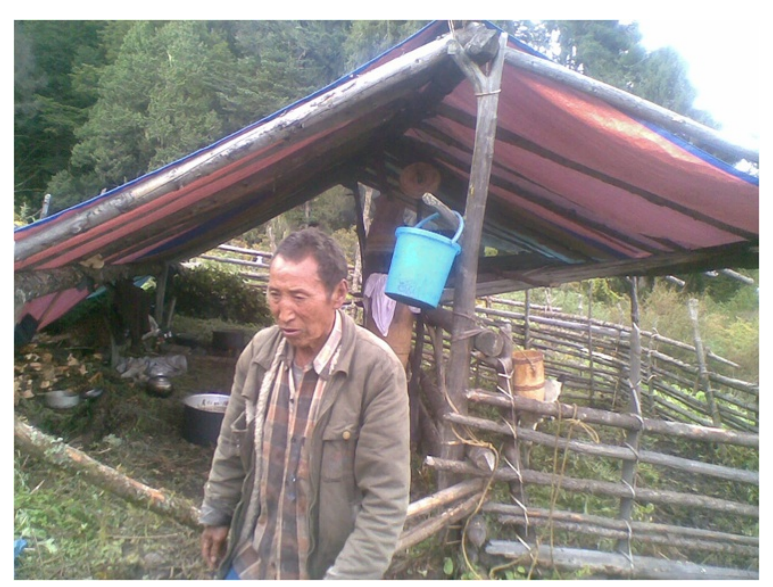

Figure $8 \mathrm{~A}$ temporary shed in one of the regular camp sites. 


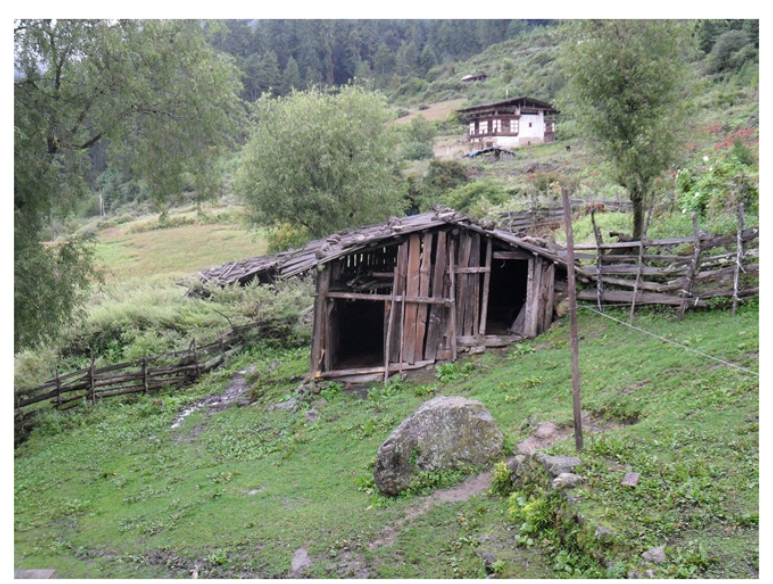

Figure 9 A typical shed constructed at homestead in temperate villages.

own decision to let animals graze the pasture on the way, and others are forced upon them because of weather and other natural calamities, wild animal attacks and general poor health condition of the animals.

\section{The timing of migration}

The timing for migrations is reportedly similar in seasons across the west and central regions of Bhutan. The herds move south in early autumn and return to temperate pastures in late spring or early summer. Migration to the south takes place between the months of September and October, whereas the returning northbound move starts in May to June.

As well as using the established calendar, other signs and indicators are used by the herders to begin the migration, including climatic indicators, as observed in village locations and the animals, as discussed next.

\section{Climatic indicators for migration}

The herders mentioned that one of the most reliable indicators for commencing migration is the drop or rise in temperatures. It is said that as autumn sets in, the ambient temperature will drop at their temperate climate village. Gradually, besides feeling chillier day by day, they start to see frosts on the ground in the mornings. This is then taken as an indication to move down to the southern Tsamdros.

Similarly, the herders said that as spring sets in and the temperature in the southern Tsamdros begins to rise, more flies and other parasites emerge. The herders also observe that their animals begin to sweat from their back as the temperatures rise. These indicators are taken seriously by the herders to initiate their north-bound return move. They also indicated that not observing these signs risks disastrous outcomes such as heavy snow at the high passes in autumn or heavy rain and storms in spring.

\section{Village location indicators of migration}

The other indicator the herders mentioned was the falling of leaves from deciduous trees and the drying up of grasses. Except for the pine trees and other evergreens, the 
areas surrounding their houses in temperate villages become dry. The growth of the grasses, controlled by grazing, is now compounded by near-freezing temperatures, thereby rendering a feed shortage for the animals. This leads to animals showing signs or initiating migration on their own accord

\section{Animal indicators of migration timing}

As the temperatures drop and feed resources become limited for animals around villages in autumn, cattle return to the homestead or their camps early with their stomachs half filled.

An elderly herder describes this:

"The cattle would bellow and look for their calves and some others would just run away. As they feel the cold on their body here and no grasses to graze, they know through experience that it is about time to move down where there is grass and is much warmer. They will follow the route and those ones that can get hold of their calves would take their calves and if the owners didn't see they would run away." (Herder_16)

Herders mentioned that they take these signs seriously and move on time. Not moving on time not only risks natural disasters but also creates disharmony with residents along the migration route because some animals that run away then stray into crops along the route. The herders said that this problem can be avoided when all the animals are together, ushered in droves under the herders' close supervision.

Additionally, milk production and therefore butter and cheese production also decline in quantity by autumn. Similarly, by spring the milk gets spoilt faster, and many flies not only bother the animals and herders alike but also get into the food.

In summary, the herders follow various signs and indicators, keenly observing their animals and the environment before making strategic moves for maintaining animals in good condition and achieving higher levels of production.

\section{Other factors that herders consider in planning their migration}

Although the transit camp sites along the routes are well established, there are several such camp sites and it is crucial for the moving herd groups to plan ahead as to which camp to reach for the day. The herders indicated that it is important to avoid being caught up in the mountains, especially in autumn should a heavy snow fall occur. The journey should be planned in such a way that the mountains are crossed or halted before they are reached, lest the herd is caught on the mountains and risks a substantial toll from heavy snow fall and extreme temperatures. Other factors the herders consider are the availability of forage resources along the way and the prevalence of wild predator carnivores. The herders from Papali and Bempu indicated that if they happen to be the first to move, they spend some time grazing the forage available along the way. This is not possible if they migrate later or in the middle of others' migrations, because they need to move faster to make space for the herds following behind them.

\section{Types of grazing rights to pasture resources}

TAPs use grazing resources commonly referred to as Tsamdros in the local language, with usufructory rights; herders do not own the land. During the interviews with the 
herders, it emerged that Tsamdro user rights (which many herders until recently assumed as exclusive private ownership) exists in three forms: private use, joint ownership between a couple of households and communal holdings.

Private Tsamdro users have exclusive rights to graze their cattle in Tsamdro registered in their household's name in the government land records register. These rights are inherited by children and become converted to joint ownership when more children need to share their parental Tsamdro. These two types of Tsamdros were more prominent in western Bhutan. In contrast, herders interviewed in Urchi and Doshi indicated that only a few households in central-east Bhutan had private Tsamdro rights. For reasons yet to be unravelled, most usufructory rights for Tsamdros in the central-east region are held in common.

Common ownership Tsamdro user rights are present in the west, but appear more usual in central-east Bhutan. Herders also reported having successful indigenous institutional arrangements in place to manage these common pool resources, including systems of allotting herders certain pastures to graze, based on their local set of rules. Herders especially in the central-east reported that the rules or the games they played to allot or combine summer-winter pastures as described by Ura (1993) are still in force and continue to be adhered to. The herders consider their system of pasture allocation to graze in commons as egalitarian, as every herder involved gets a fair chance to graze, irrespective of herd size, pasture quality or family influence.

Given the nature of their remote location and need to move seasonally, transhumance could potentially pose a serious threat to the education of herders' children and affect their life chances. This issue and how TAP herders are adapting to avail themselves of modern education opportunities for their children is presented in the next section.

\section{Transhumance and its impact on education of herders' children}

The household survey was used to determine the literacy rate of the herder communities. The in-depth interviews explored how children's education was affected by contemporary practices. Table 4 presents the literacy level of the household members of the transhumant agro-pastoralists interviewed for this research.

The literate members are either children currently in primary school or adults who attended formal or monastic schools.

The majority of herders interviewed reported that transhumance does not affect their children's education, despite the south-bound migration commencing before the school holidays begin. Owing to the different migration timings, if school-age children joined the migration, they cannot get back to school on time or finish exams to go onto the next education level. However, the interviews revealed that herders were making arrangements to allow their children to join school on time and allow them to finish

Table 4 Literacy level of household members of TAP interviewed $(n=50$ )

\begin{tabular}{lcc}
\hline Literacy level & No. of people & Percentage (\%) \\
\hline Illiterate (do not know how to read or write) & 196 & 56.65 \\
Literate (know how to read and write) & 121 & 34.97 \\
Had secondary or university level education & 29 & 8.38 \\
Total & 346 & 100.00 \\
\hline
\end{tabular}

This question was not asked in Urchi village due to an administrative error. 
exams in winter. Herders arranged for a family member to look after the children or kept them in government boarding facilities (especially teenage children) or as paying guests at acquaintances' houses.

One male herder in his mid-forties from Tshebji said that children joining the family in migration used to be the norm when he was young. He indicated that in retrospect, many like him ended up dropping out of school because their parents did not know the value of formal education and they were too young to comprehend its consequences later in life. He said that for them as children, the charm of going down to the warm places appealed more than anything, compared to having to sit exams in the torturing cold winters. However, now he says that both parents and children are aware of the value of formal education, so arrangements are made to allow children to join school on time as well as complete their final exams.

\section{Gender roles in transhumant agro-pastoralism}

Transhumant herders in our study area have separate gender roles, with men often taking the tasks that require heavier lifting or are more physically demanding such as loading the pack animals and going to the forest to collect cane for making baskets and ropes. Women mostly take care of the family, fetching water, preparing meals for the family and feeding the calves. However, the division of work becomes blurred when the household is faced with family labour shortages where men may need to engage in activities usually carried out by female members such as milking cows, and vice-versa.

In most of the herder households, there is limited farm labour, so there is no work gender differentiation between men and women. However, in some households, different gender roles do exist. Herders reported that the usual practice during migration is that men normally move ahead of the general herd with the logistics and amenities loaded on horseback or oxen, while women and children herd the general group of animals and follow from behind (Figures 10 and 11). The herders said that it is important for men to move ahead, so they can reach the camp site early and set up a camp, make shelter and makeshift corral to contain the calves, and prepare tea for the women and children. Women then prepare dinner while men collect firewood and water, gather calves in the corral, collect fodder for the calves and take stock of the animals. The herders reported that along the way, until they are settled in their winter camps, men do most of the work, often including preparing meals.

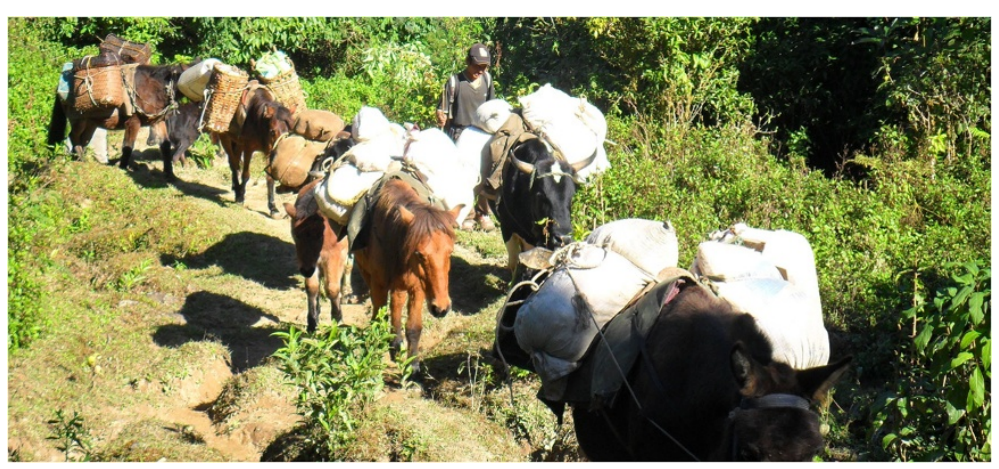

Figure $10 \mathrm{~A}$ man moving ahead with load-carrying animals. 


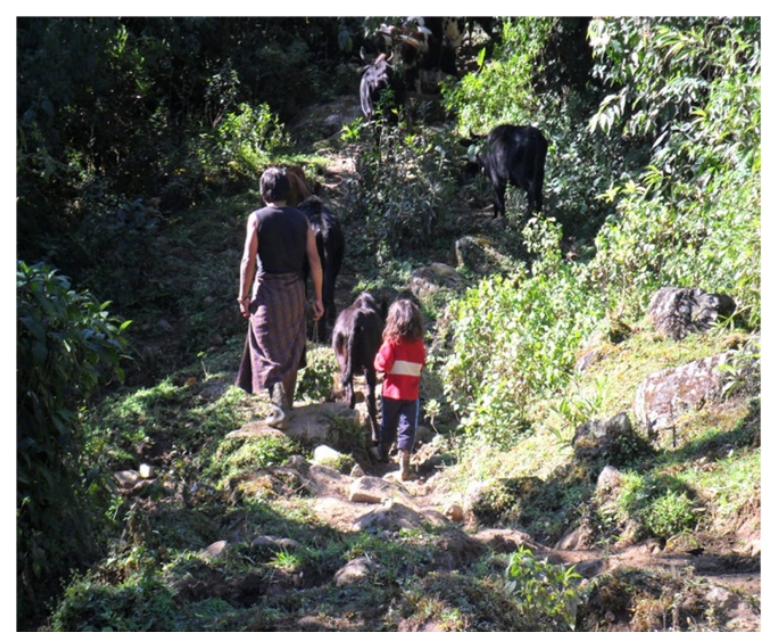

Figure 11 Women and children follow from behind with the general herd.

A herder in his fifties in Damchena said:

"During migration, men manage the pack horses and go after them because it is risky along the steep, narrow and slippery paths... Women and children will just follow from behind with packed lunch and hot tea in the flask... They could reach as late as $3 \mathrm{pm}$ at the camp because everything will be ready for them by the time they reach there..." (Herder_36)

The herders also reported that once they are settled in the winter camps, often it is the women, children and elderly who take care of the animals and process the butter and cheese while the men go with the horses to transport oranges to generate additional cash income.

\section{Socio-cultural traditions associated with TAP practices}

\section{Propitiating deities prior to migration}

The study found a number of cultural practices and social interactions associated with the transhumance system. Herders reported propitiating demigods ${ }^{i}$, appeasing local deities and performing annual rituals for their own and their animals' well-being. Some herders said that they have to perform Lha soe (a kind of shamanistic ritual appeasing demigods), while others reported performing Tshen (propitiating a local protecting deity). However, the main annual event for every household is the lo-choe or choku which is the annual well-being ritual performed by Buddhist monks, lamas and lay monks at the herders' home. These events take place prior to the south-bound migration departing from the villages.

Two herders in Damchena amongst others described the way the lo-choe or choku session begins in one household before they migrate south and others follow suit until every household in the village had conducted their session for the year:

"All chokus [annual rituals] are conducted here in the 8th month prior to migration to the south. When chokus are being conducted everyone follows each other so it sort of 
goes continuous once it is started at one place. There is nothing much being done and there is also no space or place to perform such in the southern camps." (Herder_36)

When these chokus are held, neighbours gather in that household and feast for a day with good food and alcoholic drinks provided by the host.

Herders described another event that brought the community together in celebration, which was the archery matches. During summer when the work is not heavy, the herders reported organizing inter- and intra-community archery matches where lots of food and alcohol are brought together and shared. These matches are celebrated with traditional dances, singing and good food, usually accompanied with lots of laughter.

Whilst Buddhist rituals, propitiation of local deities and appeasement of demigods for peace and well-being of herders and cattle were held in their villages, herders also built and sustained strong socio-cultural interactions and relations with the local peoples residing along their migration route and living downstream. Some of these symbolic exchanges and relations have been built over time and are presented in the following section.

\section{Social interactions and relations with other communities along the migration route}

The transhumant herders, by virtue of moving through different villages, have made friends and developed relations with many people along their route, as well as near their winter camps. Except for Papali and Bempu villagers who typically follow a route along a ridge and do not pass through any villages, all the other herders interviewed indicated that they pass through other villages, developing relationships and making friends. The herders from Doshi, Urchi, Tshebji and Damchena villages all pass through a couple of villages and have close relationships in those villages. These friendships and social networks have developed as a social safety net to be relied upon in the event of unforeseen problems along the way during migration.

Herders in Urchi and Doshi reported having particular households in the villages along their route which they consider as their hosts. As soon as their herd has arrived, the host household will come to greet them with local agricultural products and a local alcoholic brew. They have meals together and exchange gifts, and help them if they need assistance in herding their cattle or need an extra hand to manage the meat of a dead animal attacked by wild animals or which died from injury. Some gift items given by herders from Bumthang included fermented cheese, garlic and pepper.

A female herder in Damchena said:

"The communities along the way, we know each other very well so we have a good relationship. Dungna and Mondokha, even if we have a sick animal that is not able to walk we leave that behind and request them to look after it for us. Also if we lose some animals along the way, we have to seek their help... If in case an animal dies we say, please manage this meat." (Herder_35)

However, the herders from Tshebji also said that besides the normal casual dependency relations, they also have mutual reciprocal gift exchanges and some bartering between them and the communities in Mondokha and Dungna. 
One elderly herder from Tshebji said:

"... we take Ema kam (dried chillies), Kap pchee (wheat flour) and Ara (locally brewed alcoholic drink) to them. We stay several days in Dungna. Ema kam and Kap pchee are presented as gifts for which they will give us some rice in return at their own will. The Ara; we sell it to them. One bottle of Ara can fetch three dreys of rey (rice paddy). And this practice is still active..." (Herder_27)

All these interactions and relationships are likely to be lost if migration ceases. One female herder in Tshebji said that if migration ceases, people will not even know their closest family friends from these communities:

'Yes, if we don't migrate like we used to do, there won't be interactions, we won't be going to their [southern residents'] place and they won't be coming here too, so probably by our children's time we won't even know each other." (Herder_28)

Transhumant herders have developed a high level of social capital by way of building relations while sharing their culture along their routes, as well as in the south, that they can depend on in times of need and live in harmony with each other.

\section{TAP issues in Bhutan}

The results from the study also demonstrated that TAP communities in Bhutan today are faced with a number of issues, from family labour shortages to policy and climate changes that increasingly constrain them from continuing their livelihood in a business-as-usual manner. More children are attending schools - both modern and monastic education - and adults are increasingly participating in alternative livelihood options. Government policies with a strong emphasis on conservation are increasingly putting pressure on the herders; this includes reducing grazing resources, discouraging inter-district transhumant movement and encouraging sedentary farming with European dairy cattle crossbreds. Additionally, climate change ${ }^{j}$ is also increasing the risk of conducting transhumance due to a high degree of weather unpredictability. Herders indicated that, unlike in the past when they could predict the weather with a certain degree of accuracy, now they often face erratic patterns. This research has found that sudden downpours triggering floods and snowfalls while migrating put increased risk and have cost human and animals' lives. These issues will be the focus of a future paper.

\section{Discussion}

\section{TAP in Bhutan is different from most transhumant pastoral systems}

TAP in Bhutan studied here is different from most types of transhumance system or pastoralism described in the literature (Fratkin and Mearns 2003; Homewood et al. 2012). Transhumant pastoralist systems in the Himalayan region are predominantly focused on either yaks (Bishop 1989; Degen et al. 2007; Dong et al. 2009; Dorji 2002; Farooquee and Rao 1999) or small ruminants (Namgail et al. 2007; Tucker 1986). TAP in Bhutan is predominantly cattle-based with seasonal migration between specific Tsamdros either in sub-tropical forests or at temperate forests and meadows around their villages. Their permanent settlements are in temperate villages, and they have only temporary 
sheds at their designated encampments in the south. This is different from most highland systems described in the literature, where seasonal movement is between homestead pastures in winter at lower valleys and moving to higher pastures in summer (Axelby 2007; Banjade and Paudel 2009; Farooquee 1998).

Yak systems exist in Bhutan and their transhumance runs in synchrony with the cattle TAP system, such that these two groups often share the same grazing resources at temperate and sub-alpine pastures (Gyamtsho 2002). The edited volume of Kreutzmann (2012) on the vertical dimension of pastoralism in central Asian high mountains and the Tibetan plateau includes yak and yak-cattle hybrids but does not encompass the TAP cattle system which co-exists with yaks in Bhutan. TAP cattle may be seen to be competing with transhumant alpine yak pastoralism, but they are not. Timing offsets the competition (Niamir-Fuller et al. 2012). Different species' grazing behaviour too minimises competition as local cattle are good browsers, while yaks are known to be able to feed on very short swards (Gyaltsen and Dorji 2002). Additionally, seasonal migration and rotational movement between pastures per season allows for enough time for pasture regrowth, suitable for the next grazing by cattle (in sub-tropical pastures) and yaks (in temperate pastures). Moktan et al. (2008) indicated that the practice is akin to rotational grazing management regimes as practised in intensive farming systems.

Insufficient land registered as Tsamdros in a particular Dzongkhag is not always the necessary cause for Bhutanese TAP communities to engage in seasonal migration. Transhumant mobility in the study area is necessitated by a hostile winter environment in temperate altitude villages, with sub-zero temperatures and dried-up grass that render it near impossible for local cattle breeds to survive there in winter. It is therefore important for policy makers to understand that migration is dictated by environmental and seasonal changes and not out of irrational decisions of TAP herders.

\section{TAP is an important livelihood adaptation with its own socio-cultural traditions}

TAP in Bhutan as a livelihood system has adapted to the ecosystem niches and microclimate provided by altitude differences; this capitalises on the physical and climatic characteristics and plant communities. Given slow growth in the private sector and limited capacity of the government to provide infrastructure such as roads and other facilities to remote villages, the TAP cattle system in Bhutan continues to be a major livelihood system for a considerable portion of the population. Perhaps owing to the limitations imposed by natural phenomena, these inhabitants of high mountains have adapted their farming skills and raised cattle in the transhumant pastoral tradition, using natural pastures and forests for grazing. At the altitudes where these herders are located, crop production is limited as the cool temperate-to-alpine climate results in a very short growing period, but allowing for buckwheat, wheat, barley and potatoes to grow. The agro-pastoralists' preference for cattle rather than high-risk crops like potatoes gives them a level of resilience to adversity and a strong attachment to their cattle (McAllister et al. 2006).

TAP communities' persistence in retaining transhumant cattle, albeit in decline, could also be because cattle can be moved to safer places where resources are available, thus offering a flexibility which is not possible with crops. Relying solely on crops increases peoples' vulnerability at times of bad weather such as droughts or frosts, and such 
events are indicated to be occurring with increased frequency (BBS 2012a, b; Penjor 2001; Tenzin 2012). In addition, TAP communities seem to have realised the environmental, technological and market limitations of becoming a settled economy or being solely dependent on their TAP cattle. Therefore, these herders have diversified their income sources by engaging in the orange transport business, taking up various forms of petty trades, cane works and tourist services, as a means of spreading risk. This trend of seeking diversification in livelihood activities amongst pastoralists is common in other countries. Pastoralists in Africa, for example, often diversify and take up trades in the construction industry, business and petty trade. While some diversification may be out of necessity for destitute pastoralists, the better-off herders do it to spread risk and increase income sources (Homewood et al. 2012).

Generally, pastoralists' adaptation strategies include seasonal transhumance (mobility), commercialisation, sedentarisation, diversification and adoption of alternative livelihood options, similar to their cropping farmer counterparts (Ellis 1998, 2000). Essentially pastoralism as a livelihood is a highly complex system in terms of the animals kept, household self-sufficiency, migration strategies and diversification into alternative livelihood options (Davies and Bennett 2007; Mearns 2004; Mulder et al. 2010). This diversity, as Davies and Bennett (2007) mentioned, can blur the distinction of pastoralists from non-pastoral production systems. Often the income from other activities is more than the income from livestock. Some scholars indicate that in the future, part of pastoralists' income should come from payment for ecological services for their role in maintaining fragile environments and sustainable animal husbandry practices (Kreutzmann 2012).

TAP pastoralists in Bhutan have not only adapted their livelihood to changing circumstances and environment but also adjusted their socio-cultural activities around the season of transhumance. Most social activities occur in summer in their temperate villages when people are around. Archery matches and social gatherings take place in summer. It is time to get together, share and build and/or reinforce their relations and friendship. Religious activities such as propitiating deities or appeasing demigods for well-being of both people and their animals are done prior to the south-bound migration because, in the south, people are scattered in camps in the middle of forests and in temporary camps in places where there are oranges, which provide a cash-generating business. It is not only difficult in winter to find monks and shamans to perform rituals, but also people do not have time to sit back and relax as it is time for all able-bodied members to engage in cash income generation.

Such activities are important not only for their spiritual well-being but also to make new friends and reinforce existing allegiances with their close relatives and friends, which builds social capital, so important in times of family labour shortage, and to cope with environmental uncertainty. With growing connectivity through roads and telecommunications and improving economic opportunities, young herders increasingly seek out alternative livelihood options and are attracted to modern gadgets, such as television, mobile phones, rice cookers and imported compound bows. These changes could have an impact on socio-cultural norms, which can be expected to change consequently. As animals play lesser and lesser roles in the society compared to the past, new value systems will be adopted.

Socio-economic changes were observed in the Tibet Autonomous Region of Sichuan province in PRC (Iselin 2011) with changing lifestyles and adoption of motorbikes in 
place of horses. In northern India, development and integration with the market economy has had huge impact on the value systems. Younger generations are increasingly showing preference for urban lifestyles, while traditional systems that played a crucial role in the transhumant pastoralists' society in providing social cohesion and resilience to shocks are slowly giving way to more individualistic values (Farooquee 1998). The sustainability of these changed systems is, however, questionable, owing to the remoteness of the transhumant pastoral regions and the high cost of inputs that will be needed if production systems abandon traditional methods and move to more sedentarised intensive systems. Changes also increase the risk of losing the bulk of traditional knowledge and skills in animal breeding, management and the environmental ecosystems, passed down through many generations (Farooquee 1998).

In Bhutan, the negative impact of transhumant movement on children's education is not felt as much as in the past where children often helped parents during migration and had to leave school. They did not know the value of education then as there were no role models from their villages. However, as some examples appeared from their villages of people becoming educated and job opportunities arose as a result of broader national socio-economic development, parents and children have realised the value of education and are now prioritising education for their children. Today, with the combination of sheer hard work and favourable government policies such as free health and education, some TAP children have made it to some of the top universities and work in the government and private sector. TAP herders have adapted to this opportunity by adjusting or splitting family labour to allow children to attend school. Similar examples of pastoralists realizing the value of education and parents prioritising children's education can be found amongst the Tibetan-speaking pastoralists in the Ladakh region of India (Namgail et al. 2007).

Often differing views and expectations between mobile herders versus education providers tend to hinder the provision of education to mobile pastoralists' children. While mobility, for example, is seen as one of the main impediments for providing successful education, the type and relevance of education, the language and curriculum, etc. are also major problems, aside from the mismatch between expectations of education outcomes in contrast to pastoralists' cultural values (Carr-Hill and Peart 2005; Dyer 2001).

Another incidence of the high adaptability of TAP communities in Bhutan is that they have also realised the need to reduce the risk of maternal mortality and are now increasingly taking advantage of modern transport systems to seek health facilities while avoiding letting pregnant women accompany cattle migrations.

\section{Sensitive and inclusive government policies are required}

Pastoralism in Bhutan has proven to be a resilient system surviving for years, albeit in a declining trend. With no immediate scope for extensive growth in private enterprise in Bhutan, and limited possibility for intensively mechanized farming owing to the steep topography and fragmented landholdings, children may come back to continue the age-old system of TAP. Pastoral transhumance may also prove to be the system of choice in providing food in the future if current trends of a food crisis or climate and market uncertainties continue.

The indigenous knowledge of TAPs in predicting weather, locating pastures at various times of the year, and their management practices would be a valuable resource for 
successful livestock husbandry. Such local and traditional knowledge is learnt from practice, passed down orally through generations, and is not found in textbooks (Miller 1995). Transhumant pastoralists in the Himalayas are known to possess a rich and complex pool of knowledge concerning the health, behaviour and productivity of their livestock as well as their rangeland ecosystems and climatic conditions (Farooquee and Rao 1999; Nautiyal et al. 2003; Ura 2002). Given their deep knowledge of local resource distribution and ecology, pastoralists could be key partners in maintenance of ecological services and biodiversity conservation (Foggin 2012). The possibility of partnering with pastoralists to use traditional ecological knowledge (TEK) generated through their lived experience, so as to assess rangeland quality and development of management regimes, has also been suggested (Kakinuma and Takatsuki 2012; Oba 2012). Pastoralists' TEK was found to accurately assess the range productivity and thus stocking density of cattle in a given area in Mongolia (Kakinuma and Takatsuki 2012).

It is therefore necessary to explore policy options for facilitating pastoralists' continued access to resources, to reduce the risk of climate change and natural disasters and to open up new options such as eco-tourism. The Bhutanese Government will need to look into providing support for better herd management, improving migratory paths and resolving issues surrounding herders' access to Tsamdros and conflicts with people in the south. Dairy product packaging, value chain development and storage for increased shelf life, vis-à-vis marketing and transport support, will be essential for TAPs to continue their livelihood and gain access to the conventional market economy.

Pastoralists' cultural practices and rangeland management systems need proper understanding by policy makers and development practitioners, lest policies are designed based on predominant misconceptions of range degradation and over-grazing, that would affect pastoralists negatively (McGahey 2011; Niamir-Fuller et al. 2012).

\section{Conclusion}

TAP is an important part of the living cultural heritage in Bhutan. TAP herders have not only adapted their livelihood to ecological niches at different altitudinal levels but also used resources sustainably while synchronizing their socio-cultural activities with the seasonality of the practice. However, the system is under increasing pressure. Today, TAP communities are faced with family labour shortages due to increasing participation of children and adults in education and alternative livelihood options. They also face policy and climate change issues, making their TAP practice more difficult. Strategies are needed that will allow herders to make informed choices about their futures.

Research is needed to study the developing trends in TAP practice, by collecting data from across the country. Long-term anthropological and ethnographic studies are crucial to document their practices, as part of historical and educational materials for children in the future. Policies need to be designed in such a way that any alternatives suggested are evidence-based, are within the pastoral communities' means and have government support.

\section{Endnotes}

${ }^{a}$ Thrabam, Nublang and Siri are all different terms used for one indigenous cattle type in Bhutan. The term Thrabam also refers to the female, while the male of this indigenous breed is called Thalang or Nublang (official terms). See also Dorji (2011). 
${ }^{\mathrm{b}}$ Mithun (Bos frontalis) originates from Arunachal Pradesh, a northeast state of India. Bhutanese cattle keepers have long been using this technique of crossbreeding pure Mithun bulls with local Thrabam cows to produce F1 progeny - Jatsha (male; usually infertile, therefore castrated and used for ploughing and pack purposes) and Jatsham (fertile and preferred for higher milk production and higher butter fat content than local Thrabam). This indigenous cattle breeding technique existed in Bhutan before the planned development programs that promoted crossbreeding with European dairy breeds (especially Jersey and Brown Swiss) started in Bhutan. A pure Mithun called Bamen (western Bhutan) and Mencha (eastern Bhutan) bull is a very precious animal for a Bhutanese herder, and this animal will be given utmost respect and care and will not be put to any kind of work except for siring local cows.

${ }^{\mathrm{c}}$ Dzongkhag is a Bhutanese term for 'district'. Administratively Bhutan is divided into 20 Dzongkhags.

${ }^{\mathrm{d}}$ Bjobs are alpine yak herders living mainly on yaks. For details, see Gyamtsho (2000). See also Dorji (2002).

${ }^{\mathrm{e}}$ Tsamdro is a Bhutanese term for grazing areas, synonymous with pastureland, meadows or rangelands in general. Many such areas registered as Tsamdros are also in forests.

${ }^{\mathrm{f}}$ Geog is a Bhutanese term for the smallest unit of local government. A geog could comprise a few villages. The 20 Dzongkhags in Bhutan are further divided into 205 geogs.

${ }^{\mathrm{g}}$ Jatsha (male) and Jatsham (female) are F1 progenies of crossing a pure Mithun bull to a Thrabam cow. These F1 crossbreds are well known among local cattle herders for their superior production performances as compared to pure Thrabam.

${ }^{\text {h}}$ For a detailed description of Thrabam breeds, see Dorji et al. (2009).

${ }^{i}$ In Bhutan, demigods are believed to be of sub-level, inferior to the concept of god in the Buddhist belief system, but appeasing demigods brings peace and prosperity in daily life. A demigod is believed inferior because it has no power to enlighten or guide one's soul to nirvana. Though still prevalent, this culture is fast disappearing and being dominated and seen as against Buddhist belief systems, as it often involves animal sacrificial rituals.

'Owing to the lack of capacity, as well as technological constraints, the current understanding of climate change in Bhutan is based on observations of erratic weather patterns and melting of glaciers resulting in glacial lake outburst flood. For an overview of climate change in Bhutan, see RGoB and UNEP (2009).

Competing interests

The authors declare they have no competing interests.

Authors' contributions

KN carried out the major work including field work, data analysis and writing up. JM, RB and TS significantly contributed by providing guidance throughout the process and also contributed substantially in the writing up process. All authors read and approved the final manuscript.

Authors' information

KN is a PhD student in the School of Environmental Sciences at Charles Sturt University, Australia. He works as a policy planner in the Ministry of Agriculture and Forests in Bhutan. JM is a Senior Lecturer in the School of Environmental Sciences at Charles Sturt University, Australia, and is Associate Director of the Institute of Land, Water and Society. Her research expertise is in rural livelihoods and natural resource policy and planning with many years of experience in developing countries particularly Laos and Indonesia. RB is a Senior Lecturer in the School of Environmental Science at Charles Sturt University. She holds a ministerial appointment on the New South Wales National Parks and Wildlife Service Southern Ranges Region Advisory Committee and is a member of the IUCN Commission on Education and Communication. Her research interests are the social dimensions of natural resource management, sustainable tourism and environmental communication. TS is the Director of the Council for Renewable Natural Resources Research of Bhutan. His research interests are the sustainability of mixed farming systems. 


\section{Acknowledgements}

The authors wish to acknowledge the generous support of the Australian Government's AusAID for the ALA PhD scholarship and the additional support of the Institute of Land, Water and Society, Charles Sturt University, Albury, Australia.

\section{Author details}

${ }^{1}$ School of Environmental Sciences, Charles Sturt University, Albury, New South Wales 2640, Australia. ${ }^{2}$ Council for Renewable Natural Resources Research of Bhutan, Ministry of Agriculture and Forests, PO Box 119, Thimphu, Bhutan.

Received: 29 December 2012 Accepted: 28 April 2013

Published: 13 June 2013

\section{References}

Axelby, R. 2007. 'It takes two hands to clap': How Gaddi shepherds in the Indian Himalayas negotiate access to grazing. Journal of Agrarian Change 7(1): 35-75.

Banjade, MR, and NS Paudel. 2009. Mobile pastoralism in crisis: Challenges, conflicts and status of pasture tenure in Nepal mountains. Journal of Forest and Livelihood 7(1): 49-57.

BBS (Bhutan Broadcasting Service). 2012a. 180 acres of potato fields damaged by frost. Bhutan Broadcasting Service. http://www.bbs.bt/news/?p=12680

BBS (Bhutan Broadcasting Service). 2012b. A prayer for rain. Bhutan Broadcasting Service. http:/www.bbs.bt/news/?p=13770. Behnke, RH. 1983. Production rationales: The commercialization of subsistence pastoralism. Nomadic Peoples 14(1983): 3-34. Bishop, NH. 1989. From zomo to yak: Change in a Sherpa village. Human Ecology 17(2): 177-204.

Boone, RB, SB Burnsilver, JS Worden, KA Galvin, and NT Hobbs. 2008. Large-scale movements of large herbivores: Livestock following changes in seasonal forage supply. In Resource ecology: Spatial and temporal dynamics of foraging, ed. HHT Prins and F van Langevelde, 187-206. Dordrecht: Springer.

Carr-Hill, R, and E Peart. 2005. The education of nomadic peoples in East Africa. Paris/Tunis: ADB/UNESCO-IIEP. http://unesdoc.unesco.org/images/0014/001405/140563e.pdf. Accessed 10 June 2011.

Creswell, JW. 1998. Qualitative inquiry and research design: Choosing among five traditions, 1st ed. Thousand Oaks: Sage.

Davies, J, and R Bennett. 2007. Livelihood adaptation to risk: Constraints and opportunities for pastoral development in Ethiopia's Afar region. The Journal of Development Studies 43(3): 490-511.

Degen, AA, M Kam, SB Pandey, CR Upreti, S Pandey, and P Regmi. 2007. Transhumant pastoralism in yak production in the Lower Mustang District of Nepal. Nomadic Peoples 11(2): 57-85.

Dong, SK, L Wen, L Zhu, JP Lassoie, ZL Yan, KK Shrestha, and E Sharma. 2009. Indigenous yak and yak-cattle crossbreed management in high altitude areas of northern Nepal: A case study from Rasuwa district. African Journal of Agricultural Research 4(10): 957-967.

Dorji, T. 2002. Yak production systems in Bhutan. Bajo, Bhutan: Paper presented at the 5th TAPAFON meeting. http://www.fao.org/ag/AGP/agpc/doc/Proceedings/Tapafon02/tapafon3.htm. Accessed 15 Oct 2011.

Dorji, T. 2011. Genetic analysis of population structure of Bhutanese cattle reproduced by traditional cattle breeding systems. PhD Doctoral Dissertation: Kobe University, Kobe.

Dorji, T, L Tshering, and DB Rai. 2009. Conservation of the last Himalayan cattle breed of Bhutan. South Asia Pro-Poor Livestock Policy Programme (SA PPLPP): Potential Good Practice Note. Delhi.

Dunn, K. 2005. Doing qualitative research in human geography: Interviewing. In Qualitative research methods in human geography, 2nd ed, ed. I Hay, 50-81. Melbourne: Oxford University Press.

Dyer, C. 2001. Nomads and education for all: Education for development or domestication? Comparative Education 37(3): 315-327.

Dyson-Hudson, R, and N Dyson-Hudson. 1980. Nomadic pastoralism. Annual Review of Anthropology 9: 15-61.

Ellis, F. 1998. Household strategies and rural livelihood diversification. The Journal of Development Studies 35(1): 1-38.

Ellis, F. 2000. The determinants of rural livelihood diversification in developing countries. Journal of Agricultural Economics 51(2): 289-302

Ellis, JE, and DM Swift. 1988. Stability of African pastoral ecosystems: Alternate paradigms and implications for development. Journal of Range Management 41(6): 450-459.

Evans, EE. 1940. Transhumance in Europe. Geography 25(4): 172-180.

Farooquee, NA. 1998. Development and the eradication of traditional resource use practice in the Central Himalayan transhumant pastoral society. International Journal of Sustainable Development and World Ecology 5(1): 43-50.

Farooquee, NA, and KS Rao. 1999. Conservation and utilization of indigenous cattle and livestock among the transhumant pastoralists of Kumaun Himalaya (India). Journal of Environmental Systems 27(4): 317-329.

Fernandez-Gimenez, ME, and S Le Febre. 2006. Mobility in pastoral systems: Dynamic flux or downward trend? International Journal of Sustainable Development \& World Ecology 13(5): 341-362.

Foggin, M. 2012. Pastoralists and wild life conservation in western China: Collaborative management within protected areas on the Tibetan Plateau. Pastoralism: Research, Policy and Practice 2(1): 17. doi:10.1186/2041-7136-2-17.

Fratkin, E, and R Mearns. 2003. Sustainability and Pastoral livelihoods: Lessons from East African Maasai and Mongolia. Human Organization 62(2): 112-122.

Gyaltsen, T, and S Dorji. 2002. Observations on alpine grazing in Bhutan. Journal of Bhutan Studies 7: 50-60.

Gyamtsho, P. 2000. Economy of yak herders. Journal of Bhutan Studies 2(1): 90-135.

Gyamtsho, P. 2002. Condition and potential for improvement of high altitude rangelands. Journal of Bhutan Studies 7: 82-98.

Homewood, K, P Trench, and D Brockington. 2012. Pastoralist livelihoods and wildlife revenues in East Africa: a case for coexistence? Pastoralism: Research, Policy and Practice 2(1): 19. doi: 10.1186/2041-7136-2-19.

Iselin, L. 2011. Of horses and motorbikes: Negotiating modernities in pastoral Amdo, Sichuan province. Journal of the International Association of Tibetan Studies 6: 429-450.

Kakinuma, K, and S Takatsuki. 2012. Applying local knowledge to rangeland management in northern Mongolia: Do 'narrow plants' reflect the carrying capacity of the land? Pastoralism: Research. Policy and Practice 2(1): 23. doi:10.1186/2041-7136-2-23. 
Kerven, C, B Steimann, A Ashley, C Dear, and I Ur-Rahim. 2011. Pastoralism and farming in Central Asia's mountains: A research review [in English and Russian]. MSRC Background Paper No. 1. Bishkek: Kyrgyzstan University of Central Asia, Mountain Societies Research Centre. http://www.ucentralasia.org/downloads/ pastoralism_and_farming_in_central_asia_mountains.pdf.

Kreutzmann, H. 2012. Pastoral practices in transition: Animal husbandry in high Asian contexts. In Pastoral practices in High Asia: Advances in Asian Human-Environmental Research, ed. H Kreutzmann, 1-29. Berlin: Springer.

McAllister, RRJ, IJ Gordon, MA Janssen, and N Abel. 2006. Pastoralists' responses to variation of rangeland resources in time and space. Ecological Applications 16(2): 572-583.

McGahey, DJ. 2011. Livestock mobility and animal health policy in southern Africa: the impact of veterinary cordon fences on pastoralists. Pastoralism: Research, Policy and Practice 1(14): doi: 10.1186/2041-7136-1-14.

McVeigh, C. 2004. Himalayan herding is alive and well: The economics of pastoralism in the Langtang valley. Nomadic Peoples 8(2): 107-124.

Mearns, R. 2004. Sustaining livelihoods on Mongolia's pastoral commons: Insights from a participatory poverty assessment. Development and Change 35(1): 107-139. doi:10.1111/j.1467-7660.2004.00345.x.

Miehe, G, S Miehe, K Kaiser, C Reudenbach, L Behrendes, and F Schlütz. 2009. How old is pastoralism in Tibet? An ecological approach to the making of a Tibetan landscape. Palaeogeography, Palaeoclimatology, Palaeoecology 276(1-4): 130-147.

Miller, D. 1995. Herds on the move: Winds of change among pastoralists in the Himalayas and on the Tibetan Plateau. Kathmandu: ICIMOD.

Mishra, C, S Bagchi, T Namgail, and YV Bhatnagar. 2010. Multiple use of trans-Himalayan rangelands: Reconciling human livelihoods with wildlife conservation. In Wild rangelands: Conserving wildlife while maintaining livestock in semi-arid ecosystems, ed. JT du Toit, R Kock, and JC Deutsch, 291-311. Chichester: Wiley-Blackwell.

Misra, M. 2009. Mobile pastoralists in Iran's arid lands. International Jounal of Environmental Studies 66(3): 357-370.

MoA (Ministry of Agriculture). 2009. RNR Census 2008. Thimphu: Policy and Planning Division, Ministry of Agriculture.

Moktan, MR, L Norbu, H Nirola, K Dukpa, TB Rai, and R Dorji. 2008. Ecological and social aspects of transhumant herding in Bhutan. Mountain Research and Development 28(1): 41-48.

Mulder, MB, I Fazzio, W Irons, RL McElreath, S Bowles, A Bell, and L Hazzah. 2010. Pastoralism and wealth inequality. Current Anthropology 51(1): 35-48.

Namgail, T, YV Bhatnagar, C Mishra, and S Bagchi. 2007. Pastoral nomads of the Indian Changthang: Production system, landuse and socioeconomic changes. Human Ecology 35(4): 497-504.

Nautiyal, S, KS Rao, RK Maikhuri, and KG Saxena. 2003. Transhumant pastoralism in the Nanda Devi Biosphere Reserve, India: A case study in the buffer zone. Mountain Research and Development 23(3): 255-262.

Niamir-Fuller, M. 2005. Managing mobility in African rangelands. In Collective action and property rights for sustainable rangeland management. CAPRi research brief, 5-6. Washington, DC: CAPRi.

Niamir-Fuller, M, C Kerven, R Reid, and E Milner-Gulland. 2012. Co-existence of wildlife and pastoralism on extensive rangelands: Competition or compatibility? Pastoralism: Research. Policy and Practice 2(1): 1-14. doi:10.1186/2041-7136-2-8.

NSB (National Statistical Bureau). 2007. Statistical yearbook of Bhutan 2007. Thimphu: National Statistics Bureau, Royal Government of Bhutan.

NSB (National Statistical Bureau). 2008. Socio-economic and demographic indicators 2005. Thimphu: National Statistics Bureau, Royal Government of Bhutan.

NSB (National Statistical Bureau). 2011. Statistical year book 2011. Thimphu: National Statistical Bureau, Royal Government of Bhutan.

Noy, C. 2008. Sampling knowledge: The hermeneutics of snowball sampling in qualitative research. International Journal of Social Research Methodology 11(4): 327-344. doi:10.1080/13645570701401305.

Oba, G. 2012. Harnessing pastoralists' indigenous knowledge for rangeland management: Three African case studies. Pastoralism: Research, Policy and Practice 2: 1. doi:10.1186/2041-7136-2-1.

Patton, MQ. 1990. Qualitative evaluation and research methods. Thousand Oaks: Sage.

Penjor, U. 2001. Drought takes toll on food crops in the east. Kuensel. http://www.kuenselonline.com/drought-takestoll-on-food-crops-in-the-east/.

PPD (Policy and Planning Division). 2008. Compendium of renewable natural resources statistics. Thimphu: Policy and Planning Division, Ministry of Agriculture, Royal Government of Bhutan.

RGoB (Royal Government of Bhutan). 2009. RNR Sector Tenth Plan (2008-2013): Enabling farming communities to overcome poverty (Vol. I: Main document). Thimphu: Ministry of Agriculture, Royal Government of Bhutan

RGoB, and UNEP. 2009. Strategizing climate change for Bhutan. Thimphu: National Environment Commission.

Rota, A, and S Sperandini. 2009. Livestock and pastoralists. IFAD: Livestock Thematic Papers - Tools for Project Design. Rome.

Sandford, S. 1983. Management of pastoral development in the third world. London: Wiley.

Scoones, I. 1994. Economic and ecological carrying capacity applications to pastoral systems in Zimbabwe. In Economics and ecology: New frontiers and sustainable development, ed. EB Barbier, 96-117. London: Chapman \& Hill.

Tenzin, T. 2012. Compensation in kind distributed for frost damaged crops. Kuensel. http://www.kuenselonline.com/2011/?p=32281.

Tong, A, P Sainsbury, and J Craig. 2007. Consolidated criteria for reporting qualitative research (COREQ): A 32-item checklist for interviews and focus groups. International Journal for Quality in Health Care 19(6): 349-357. doi:10.1093/intqhc/mzm042.

Tucker, RP. 1986. The evolution of transhumant grazing in the Punjab Himalaya. Mountain Research and Development 6(1): $17-28$

Ura, K. 1993. The nomads gamble: Pastoralists of northern Bhutan. South Asia Research 13(2): 81-100.

Ura, K. 2002. The herdsmen's dilemma. Journal of Bhutan Studies 7: 1-43.

Waters-Bayer, A, and W Bayer. 1992. The role of livestock in the rural economy. Nomadic Peoples 31: 3-18.

Westbrook, L. 1994. Qualitative research methods: A review of major stages, data analysis techniques, and quality controls. Library and Information Science Research 16: 241-254.

doi:10.1186/2041-7136-3-13

Cite this article as: Namgay et al:: Transhumant agro-pastoralism in Bhutan: Exploring contemporary practices and socio-cultural traditions. Pastoralism: Research, Policy and Practice 2013 3:13. 